\title{
Neuropathic Back Pain Caused by Ectopic Thyroid
}

\author{
Ektopik Tiroid Nedeniyle Nöropatik Sırt Ağrısı
}

Cansel Atinkaya Öztürk', Mustafa Vayvada', Murat Kavas², Volkan Baysungur', İrfan Yalçınkaya'

\begin{abstract}
The posterior mediastinum is an atypical localization for thyroid tumors. The incidence of mediastinal goiter varies from $0.16 \%$ to $3.3 \%$ in thyroid tumors. Symptoms related to tumor size and its relationship with surrounding tissues may appear. Neuropathic pain is an extremely rare finding caused by an ectopic thyroid. We present here a 42 -year-old male patient suffering from neuropathic pain in his back. Thoracic computed tomography and magnetic resonance imaging showed a smooth-bordered mass approximately $8 \times 10 \mathrm{~cm}$ in size located in the paravertebral sulcus and compressing both the trachea and the esophagus. The tumor was diagnosed as ectopic thyroid and completely resected through a thoracotomy, with relief of pain postoperatively.
\end{abstract}

Key words: Ectopic thyroid, posterior mediastinal mass, neuropathic pain.

\section{Özet}

Posterior mediasten, ektopik guatr için atipik bir lokalizasyondur. Mediastinal guatr görülme sıklığı tiroid tümörleri arasında \%0,16 ila \%3,3 arasındadır. Semptomlar tümör boyutu ve çevre dokularla olan bağlantılarına göre değişmektedir. Ektopik tiroide bağlı nöropatik ağrı son derece nadir bir bulgudur. Burada, 42 yaşında, sırtında nöropatik ağrı şikâyeti olan bir hastayı sunuyoruz. Toraks bilgisayarlı tomografi ve manyetik rezonansla görüntülemede düzgün sınırlı, yaklaşık $8 \times 10 \mathrm{~cm}$ boyutlarında, paravertebral sulkusta, trakea ve özofagusa bası yapan kitle saptandı. Tümör ektopik tiroid olarak teşhis edildi ve torakotomi ile tamamen çıkarıldı ve postoperatif dönemde nöropatik ağrı şikâyeti gözlenmedi.

Anahtar Sözcükler: Ektopik guatr, posterior mediastinal kitle, nöropatik ağrı.
Ectopic thyroid tissue is a rare developmental abnormality. Its prevalence is about 1 per 100000 300000 people $(1,2)$. The posterior mediastinum is an atypical location for an ectopic thyroid. Mediastinal thyroids make up $0.16 \%$ to $3.3 \%$ of thyroid tumors but the incidence of posterior mediastinal localization for primary thyroid tumors is unknown (3). Most cases are asymptomatic.
Common symptoms include cough, pain, dysphagia, dysphonia, dyspnea and hemorrhage. Neuropathic pain is a very rare symptom caused by ectopic thyroid and until now there is only one case report published in the English literature. We present an ectopic thyroid case with unusual localization and lightning-like back pain.
'Department of Thoracic Surgery, Süreyyapaşa Chest Diseases and Thoracic Surgery Training and Research Hospital, İstanbul, Turkey

${ }^{2}$ Department of Chest Diseases, Süreyyapaşa Chest Diseases and Thoracic Surgery Training and Research Hospital, İstanbul, Turkey

Correspondence (iletişim): Cansel Atinkaya Öztürk, Department of Thoracic Surgery, Süreyyapaşa Chest Diseases and Thoracic Surgery Training and Research Hospital, İstanbul, Turkey e-mail: catinkaya@gmail.com 


\section{CASE}

A 42-year-old male patient presented with dyspnea, sudden lightning-like backache, hyperesthesia in his back, difficulty in swallowing and shortness of breath. The patient complained of night backache disturbing sleep and pain that increased when lying supine. The laboratory values and thyroid function tests were within normal limits Neck ultrasonography (USG) did not reveal any connection between the cervical thyroid and ectopic thyroid. Thoracic computed tomography and magnetic resonance imaging (MRI) showed a smooth-bordered mass approximately $8 \times 10 \mathrm{~cm}$ in size, located in the paravertebral sulcus, and compressing the trachea and esophagus (Figure 1a). Thoracotomy from the right fourth intercostal space showed a smooth bordered mass rich in vascular collaterals that extended from the upper mediastinum to the cervical region. The mass was excised by means of the LigaSure Vessel Sealing System (Valley Lab, Boulder, $\mathrm{CO}$ ) (Figure 1b). The cuff of the intubation tube was seen behind the trachea at the end of the excision of the mass. A vertical laceration of the membranous wall, approximately $5 \mathrm{~cm}$ in length, caused by difficult intubation, was observed. The membranous wall was repaired with interrupted 4/0 polypropylene sutures. The pathology result was ectopic thyroid. The postoperative course was uneventful and there were no complications during the one month and six month follow-up.

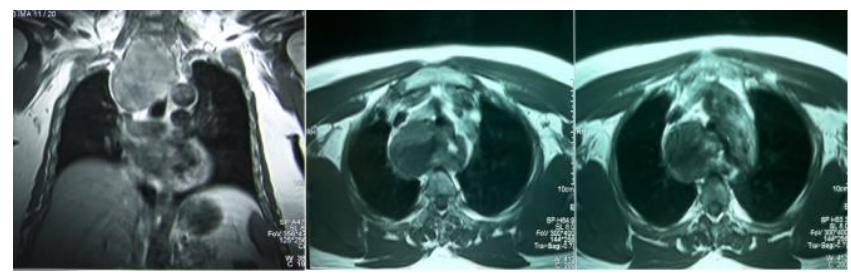

Figure 1a: On MRI sections, a smooth-bordered mass approximately $8 \times 10 \mathrm{~cm}$ in size located in the paravertebral sulcus and compressing the trachea and esophagus

\section{DISCUSSION}

To our knowledge, this case is only the second case in the English literature with neuropathic pain. The pain is thought to be due to the spinal cord of the patient being compressed by the mass at the thoracic inlet. The complete recovery of pain and hyperesthesia in his back after the mass was excised indicates that it was due to a temporary compressive effect.

Ectopic thyroid has been reported in the mediastinum, lungs, and heart, usually manifesting with a dry cough, dyspnea, and hemoptysis. Less commonly, patients may present with dysphagia or the superior vena cava syn- drome. The symptoms may occur due to trachea, esophagus, superior vena cava, and vertebral cord compression. Deda et al (4) reported a seven-year-old case with neuropathic pain.

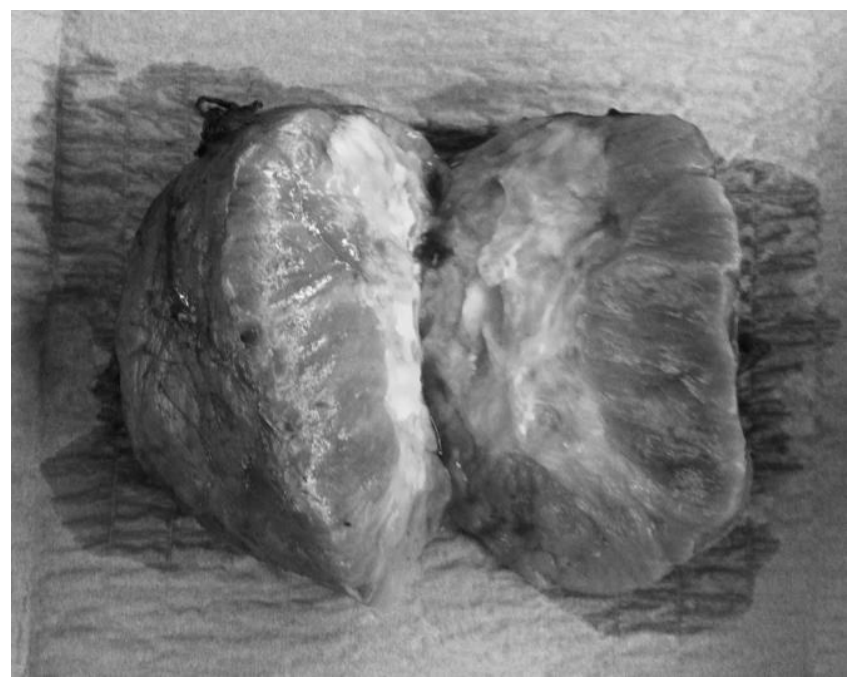

Figure 1b: Macroscopic view of the resected ectopic thyroid material

Ectopic intrathoracic thyroid tissue makes up less than $1 \%$ of all the surgically resected mediastinal masses. The ectopic thyroid tissue is usually close to the thymus and in close relationship to the thymothyroid ligament. It has also been defined in the pericardium and the heart. The intratracheal thyroid is another rarely described location for ectopic thyroid. It results from the developing thyroid tissue growing into the trachea or cartilage rings, or the growth of the thyroid tissue into the trachea lumen. A thyroid, fully located in the posterior mediastinum, is quite rare. It is usually located in the right hemithorax as seen in our case. The reason is thought to be the obstruction of the descending pathway of the ectopic thyroid tissue on the left of the aortic arch (5).

Malignant transformation is uncommon. Ectopic thyroid is more common in females. It may occur at any age, from five months to 40 years, but Chest CT and MRI are valuable tools for identifying the site of ectopy, especially when it is distant from the descending pathway of thyroid. The neck should be examined for a normally located thyroid gland. CT and MRI may predict the malignancy potential of the ectopic thyroid (6).

Surgery for mediastinal goiters should always be considered, even in elderly patients, because of the high risk of tracheal compression and the low morbidity of the surgery. Its removal usually necessitates thoracotomy or sternotomy. Most of the anterior mediastinal thyroids can be removed using a transcervical approach; however posterior mediastinal thyroids may require additional 
extracervical incisions. The mass was totally removed in our case but there was some difficulty with the surgical removal of the upper pole. Thoracotomy was performed because of localization in the paravertebral sulcus of the thyroid. It could not be easily accessible via partial sternotomy to paravertebral sulcus. If the upper pole was not removed, freeing of the upper pole could be attempted through a necklace incision or partial sternotomy.

In conclusion, ectopic thyroid is seen rarely in the posterior mediastinum and there are no ectopic thyroid cases in the literature that have caused neuropathic back pain due to such localization.

\section{CONFLICTS OF INTEREST}

None declared.

\section{AUTHOR CONTRIBUTIONS}

Concept - C.A.Ö., M.V., M.K., V.B., I.Y.; Planning and Design - C.A.Ö., M.V., M.K., V.B., I.Y.; Supervision C.A.Ö., M.V., M.K., V.B., I.Y.; Funding - M.K.; Materials - M.K.; Data Collection and/or Processing - M.V.; Analysis and/or Interpretation - M.K.; Literature Review - V.B.; Writing - I.Y.; Critical Review - C.A.Ö.

\section{YAZAR KATKILARI}

Fikir - C.A.Ö., M.V., M.K., V.B., İ.Y.; Tasarım ve Dizayn C.A.Ö., M.V., M.K., V.B., I.Y.; Denetleme - C.A.Ö., M.V.,
M.K., V.B., I.Y.; Kaynaklar - M.K.; Malzemeler - M.K.; Veri Toplama ve/veya İşleme - M.V.; Analiz ve/veya Yorum - M.K.; Literatür Taraması - V.B.; Yazıyı Yazan - I.Y.; Eleştirel İnceleme - C.A.Ö.

\section{REFERENCES}

1. Babazade F, Mortazavi H, Jalalian H, Shahvali E. Thyroid tissue as a submandibular mass: a case report. J Oral Sci 2009; 51:655-7. [CrossRef]

2. Di Benedetto V. Ectopic thyroid gland in the submandibular region simulating a thyroglossal duct cyst: a case report. J Pediatr Surg 1997; 32:1745-6. [CrossRef]

3. Hashmi SM, Premachandra DJ, Bennett AM, Parry W. Management of retrosternal goitres: results of early surgical intervention to prevent airway morbidity, and a review of the English literature. J Laryngol Otol 2006; 120:6449. [CrossRef]

4. Deda G, Tezic T, Karagol U, Akinci A, Kokes F, Akcayuz A. Ectopic thyroid tissue causing cord compression. Turkish Neurosurgery 1991 ; 2:77-9.

5. Shah BC, Ravichand CS, Juluri S, Agarwal A, Pramesh CS, Mistry RC. Ectopic thyroid cancer. Ann Thorac Cardiovasc Surg 2007; 13:122-4.

6. Yoo SC, Chang KH, Lyu MO, Chang SJ, Ryu HS, Kim HS. Clinical characteristics of struma ovarii. J Gynecol Oncol 2008; 19:135-8. [CrossRef] 